\title{
Hakekat Penjatuhan Pidana Pengawasan yang diberikan oleh Hakim terhadap Anak yang Berhadapan dengan Hukum guna mewujudkan Keadilan
}

\author{
Ifahda Pratama Hapsari, \\ 1,2,3) Staf pengajar Hukum, Prodi Ilmu Hukum Universitas Muhammadiyah Gresik \\ *korespondensi: ifa.zegeeg@gmail.com
}

\begin{abstract}
ABSTRAK
.Kekuasaan Kehakiman merupakan salah satu unsur penting dalam struktur ketatanegaraan yang menjadi bagian dari sistem Hukum suatu negara. Dalam konsep Negara hukum termasuk pula konsep Rechtstaat, maupun the rule of law serta nomokrasi islam. kekuasaan kehakiman menjadi tiang penyangga suatu negara hukum bekerja. dalam negara hukum kekuasaan kehakiman dituntut dituntut harus bebas atau merdeka dari pengaruh siapapun terpisah dari kekuasaan legislatif dan yudikatif. Pada dasarnya, pidana pengawasan yang diterapkan hakim kepada anak yang berhadapan dengan Hukum harus mencerminkan keadilan. kata pidana pada umumnya tidak lazim diberikan kepada anak. maka diharapkan pemberian sanksi pidana atau hukuman diganti dengan pemaknaan yang lebih baik yaitu dengan melakukan pengawasan, yang jauh lebih efektif diterapkan agar tidak menimbulkan stigmatisasi terhadap anak yang sedang berhadapan dengan hukum.
\end{abstract}

Kata Kunci: Hakekat, Pidana Pengawasan, Anak yang berhadapan Hukum, Keadilan

\section{PENDAHULUAN}

Menurut locke kekuasaan negara seperti yang dikemukaakan oleh John Locke filsuf inggris terbagai menjadi 3 yaitu:

1. Kekuasaan eksekutif

2. Kekuatan legisltaif

3. Kekuasaan yudikatif

pembagian kekuasaan ini adalah sesuai dengan kebudayaan pribadi bangsa Indonesia dibidang penyusuana Ketatanegaraan nasional seperti ternyata dalam negara-negara Indonesia Merdeka berdaulat sepanjang masa, penyusunan Ketatanegaraan yang bersumber kepada proklamasi kemerdekaan indonesia 1945 itu adalah Pelaksanaan kemerdekaan dalam tatanan Hukum Konstitusional dengan menurutkan tuntutan-tuntutan modern ditanah indonesia dari tanah asing tahun 1776-1945. Pembagian Kekuasaan Pemerintah berlangsung dalam kesatuan pemerintah yang bulat dan semata-mata untuk memperteguh persatuan dengan menjamin kelancaran administrasi dan kebebasan rakyat indonesia. Jadi pembagian Kekuasaan adalah untuk memberantas perpecahan dalam masyarakat dan untuk menjamin kesatuan tindakan (I'unite d'action) dalam negara RI yang tidak mengenal Pemusatan Kekuasaan melainkan dalam satu tangan manusia (la concentration du pouvoir) melainkan mewujudkan kesatuan dan persatuan nasional dalam 
republik indonesia yang "une et indevisible" esa dan (tanpa terbagi-bagi) dalam jiwa dan tujuan dan tujuan tindakan dalam membela kemerdekaan, sehingga demokrasi terpimpin dan ekonomi terjamin pelaksannannya.

Dalam Pelaksanaan Penjatuhan Pidana khusunya dalam hal Kata Pidana identik dengan Pemberian saksi dan hukuman penjara.

Meskipun pidana penjara merupakan pidana utama yang diancamkan dan dilaksanakari oleh mayoritas negara, sejak dahulu sampai saat ini efektivitas pidana penjara diragukan. Bahwa berdasarkan hasil penelitian Djisman Samosir di Lembaga Pemasyarakatan Cipinang pada tahun 1990 menemukan bahwa delapan puluh lima orang dari 100 narapidana yang diteliti menyatakan, bahwa pidana penjara bukan sesuatu yang menakutkan, karena sebelum melakukan tindak pidana sudah mengetahui tentang risiko dari perbuatannya yaitu dijatuhi pidana penjara Karena itu, pidana penjara makin banyak mendapat sorotan tajam dari para ahli penologi.

Sistem pemidanaan di Indonesia serta bagaimana pengaturan pidana pengawasan dalam sistem pemidanaan sebagai suatu upaya pembaharuan hukum pidana di Indonesia dalam kaitannya dengan pidana penjara, Pertama, sesuai dengan politik hukum pidana maka tujuan pemidanaan harus diarahkan kepada perlindungan masyarakat dari kejahatan. Oleh karena itu, ide dasar diwujudkannya pidana pengawasan sebagai alternatif jenis pidana perampasan kemerdekaan (penjara) dalam hukum pidana di Indonesia seharusnya selaras dengan kedua aspek dari tujuan pemidanaan tersebut.

Kedua Dalam penjelasan Rancangan KUHP Nasional tersebut dinyatakan, bahwa pelaksanaan pidana pengawasan ini dikaitkan dengan ancaman pidana penjara. Pidana pengawasan adalah bersifat alternatif pidana perampasan kemerdekaan bersyarat, yaitu adanya ketentuan untuk tidak dijalankannya pidana yang telah dijatuhkan (yang berkaitan dengan pidana penjara) dengan diadakannya syarat-syarat tertentu dan ditetapkan masa percobaan paling lama 3 tahun.

Ketiga, Pidana bersyarat sebagai alternatif pidana perampasan kemerdekaan dalam KUHP yang berlaku sekarang masih kurang memberikan perlindungan terhadap individu / pelaku tindak pidana. Oleh karena itu, untuk menentukan formulasi alternatif pidana perampasan kemerdekaan dalam KUHP Nasional di masa yang akan datang, diperlukan sarana alternatif pidana perampasan kemerdekaan yang lain, seperti pidana pengawasan (probation) yang telah banyak dikembangkan di negara- negara lain. 
Negara Indonesia sendiri, Pidana Pengawasan itu dan pemberian penjatuhan putusannya merupakan bagian dari Pidana yang diletakan pada syarat tertentu yang diatur didalam Pasal 14 a. Pasal 14 a KUHP secara garis besar menyebutkan, bahwa terhadap terpidana yang akan dijatuhi pidana penjara kurang dari 1 (satu) tahun, kurungan bukan pengganti denda dan denda yang tidak dapat dibayar oleh terpidana dapat diganti dengan pidana bersyarat. Dengan demikian terhadap pelaku tindak pidana/terdakwa telah ada penjatuhan pidana secara pasti, yang pelaksanaannya ditunda dengan bersyarat, sehingga telah terjadi proses stigmatisasi terhadap pelaku tindak pidana melalui keputusan hakim yang disampaikan dalam sidang yang terbuka untuk umum.

Dari hasil penelitian dapat ditarik kesimpulan bahwa Ide dasar diadakannya pidana pengawasan yaitu untuk menggantikan pidana perampasan kemerdekaan/penjara yang dalam perkembangannya telah menimbulkan efek negatif bagi kepentingan terpidana dan kepentingan masyarakat. Pidana pengawasan seharusnya dimasukkan sebagai salah satu jenis pidana pokok. KUHP Nasional di masa yang akan datang, diperlukan sarana alternatif pidana perampasan kemerdekaan yang lain, seperti pidana pengawasan (probation) yang telah banyak dikembangkan di negara- negara lain.

Berdasarkan latar belakang penelitian diatas, maka dibuatlah suatu permasalahan yaitu Hakekat Penjatuhan Pidana Pengawasan yang diberikan oleh Hakim terhadap Anak yang Berhadapan dengan Hukum

\section{METODE PENELITIAN}

Jenis penelitian yang digunakan adalah penelitian hukum normatif yaitu penelitian yang mengkaji peraturan perundang-undangan yang mempunyai keterkaitan dengan obyek kajian penelitian khususnya mengenai asas-asas dan norma hukum yang tertuang dalam peraturan perundang-undangan dan Dalam penelitian ini, metodependekatan yang digunakan adalah Pendekatan Perundang-Undangan (Statute Approach) dan Pendekatan Konsep (ConseptualApproach).

Pendekatan Perundang-undangan (Statute Approach), yaitu pendekatan dengan cara mengkaji dan menelaah peraturan perundang-undangan dan regulasi yang bersangkut paut dengan pokok permasalahan penelitian.

Pendekatan Konsep (Conseptual Approach), yaitu pendekatan dengan cara mempelajari pandangan dan doktrin dalam ilmu hukum, konsep, asas hukum yang relevan dengan pokok permasalahan penelitian 


\section{HASILDAN PEMBAHASAN}

\section{Hakekat penjatuhan Pidana Pengawasan oleh Hakim terhadap Anak yang berhadapan dengan Hukum}

Penanggulangan kejahatan dengan menggunakan (hukum) pidana merupakan cara yang paling tua, setua peradaban manusia itu sendiri. Pidana merupakan istilah yang lebih khusus dari "hukuman" yang menurut Sudarto bahwa "yang dimaksud dengan pidana ialah penderitaan yang sengaja dibebankan kepada orang yang melakukan perbuatan yang memenuhi syarat-syarat tertentu.Kata " tindak pidana” merupakan terjemahan dari "straffbaar feit", Moeljatno memakai istilah "perbuatan pidana" oleh karena pengertian perbuatan lebih abstrak sehingga lebih luas dari pengertian tindak yang hanya menyatakan keadaan kongkrit, Tirtaamidjaja memakai istilah "pelanggaran pidana" dan Utrecht memakai istilah "peristiwa pidana". Lebih lanjut dikatakan bahwa pada umumnya tindak pidana disinonimkan dengan delik, yang berasal dari bahasa latin yakni delictum. Dalam kamus besar bahasa Indonesia delik artinya perbuatan yang dapat dikenakan hukuman karena merupakan pelanggaran terhadap undang- undang tindak pidana.Unsur-unsur yang terdapat dam pengertian diatas yaitu :

(1) Ada suatu perbuatan,

(2) Perbuatan itu dapat dikenakan hukuman, dan

(3) Perbuatan itu melanggar Undang-Undang tindak pidana Definisi hukum pidana menurut Sudikno Mertokusumo yaitu:

"Hukum pidana adalah hukum yang menentukan perbuatan-pebuatan apa atau siapa sajakah yang dapat dipidana serta sanksi-sanksi apa sajakah yang tersedia. Hukum pidanan dibagi menjadi hukum pidana materil dan hukum pidana formil. Hukum pidana materil ini membuat perbuatan-perbuatan melanggar hukum yang disebut delik dan yang diancam dengan sanksi. Hukum pidana formil atau hukum acara pidana mengatur bagaimana caranya negara menerapkan sanksi pidana pada peristiwa kongkrit Menurut Prodjohamidjojo bahwa: "hukum pidana ialah bagian dari keseluruhan hukum yang berlaku di suatu negara yang mengadakan dasar-dasar dan aturan-aturan untuk .Menentukan perbutan-perbuatan mana yang tidak boleh dilakukan. Sedangkan Menurut Schaffmeiter Perbuatan yang menyalahi apa yang telah diatur dalam ketentuan pidana tersebut adalah perbuatan yang melawan hukum. Schaffmeiter et. al, yang diterjemahkan oleh JE.Sahetapy membagi sifat melawan hukum menjadi empat makna yaitu : 
a) sifat melawan hukum umum,

b) sifat melawan hukum khusus,

c) sifat melawan hukum formal dan

d) sifat melawan hukum materil. Sifat melawan hukum formal berarti :" semua bagian yang tertulis dari rumusan delik telah dipenuhi (jadi semua syarat tertulis untuk dapat dipidana), sedangkan sifat melawan hukum yang hendak dilindungi oleh pembentuk undang-undang dalam rumusan delik tertentu.

Menurut Mertokusumo

"Pelaksanaan hukum dapat berarti menjalankan hukum tanpa ada sengketa atau pelanggaran. Ini meliputi pelaksanaan hukum oleh setiap warga negara setiap hari yang tidak disadarinya dan juga aparat negara, seperti misalnya polisi yang berdiri di perempatan jalan mengatur lalu lintas (Law enforcement). Di samping itu pelaksanaan hukum dapat terjadi kalau ada sengketa, yaitu yang dilaksanakan oleh hakim. Ini sekaligus merupakan penegakan hukum".

Lebih lanjut Mertokusumo mengatakan bahwa dalam menegakan hukum ada tiga unsur yang selalu harus diperhatikan, dalam upaya melaksanakan suatu putusan dalam kaitannya dalam pidana pengawasan yaitu :kepastian hukum (rechticherheit), kemanfaatan (zweckmassigkeit) dan keadilan (gerechtigkeit). Kepastian hukum merupakan perlindungan yustisiabel terhadap tindakan sewenang-wenang yang berarti bahwa seseorang akan dapat memperoleh sesuatu yang diharapkan dalam keadaan tertentu. Fiat justitia et pereatmundus (meskipun dunia ini runtuh hukum harus ditegakan). Sebaliknya "masyarakat mengharapkan manfaat dalam pelaksanaan atau penegakan hukum. Demikian juga keadilan adalah hal yang harus diperhatikan dalam penegakan hukum yang harus dapat memberikan keadilan bagi masyarakat.

Pada Hakikatnya.asas atau prinsip hukum yang bernama kebebasan atau kemerdekaan kekuasaan kehakiman atau kebebasan kekuasaan Badan peradilan tidak hanya berlaku di Indonesia saja . Sumber refrensi bahwa prinsip tersebut juga dikenal di dunia internasional dengan dikatakan mengacu pada hal tersebut dikatakan bahwa asas universal dianut di negara-negara dunia. hal ini dalam basic Principles on independence of the judiciary yang diajukan oleh Majelis umum PBB (Resolusi 40/32 tanggal 29 November 1985 dan Resolusi 40/146 tanggal 13 Desember 1985. prinsip of the independence The law asian Region of the Judiciaary di manila tanggal 28 agustus 1977 didalam bejing Statement ditegaskan bahwa:

“1.Kehakiman Merupakan institusi nilai-nilai tertinggi pada setiap masyarakat 
2. Kemerdekaan mempersyaratkan bahwa hakim memutuskan sebuah perkara sepenuhnya atas dasar Pemahaman Undang-undang dan terbebas dari pengaruh dari manapun baik langsung maupun tidak langsung, hakim memiliki yuridiksi atas segala isu yang memerlukan keadilan.

Makna atas kekuasaan Kehakiman mengenai hakekat keadilan untuk menjatuhkan Putusan Pidana Pengawasan bagi anak ,yang merdeka dan bebas sebagaimana dikemukaakan diatas, sudah diberi dimensi fungsional. fungsional dalam pengertian bahwa makna seperti itu menuntut pelaksanaan fungsi Kekuasaan Kehakiman dalam menyelsaikan kasus sengketa baik itu (Perselisihan Perdata, Tata Usaha Negara dan perkara kasus Pidana). yang diperiksa oleh Hakim

Hakim disini, Ketika Memeriksa Sebuah Perkara dalam hal Anak, Harus dilihat terlebih dahulu, sumber Peraturan yang ada dan/berlaku, asal peraturan tersebut tepat atau tidak tepat terhadap perkara yang diperiksa. serta penjatuhan pemidanaan apakah sesuai bagi anak yang berhadapan dengan hukum. Terhadap anak sebagai Pelaku tindak Pidana kadangkala Masyarakat dan pemerintah dalam hal penegak Hukum kurang arif melihat permasalahan tersebut anggapan sebagai anak nakal atau penjahata sering diberikan kepada mereka. bahkan dalam proses peradilan Anak, diperlakukan tidak adil sehingga terkesan anak pelaku tindak Pidana menjadi korban struktur dari penegak hukum.

Penanganan Anak yang berhadapan dengan Hukum terutama anak sebagai pelaku tindak pidana memang bermasalah. Dalam Seminar dan Workshop dibogor tanggal 5-6 April 2010 Patrialis akbar Menteri Hukum dan HAM dalam penanganan anak yang bermasalah dengan hukum sedapat mungkin dengan Pendekatan Restoratif justice. lebih lanjut dikatakan bahwahasil pantauannya adalah dilapas/rutan menunjukan kenyataan yang hampir sama, anak anak yang berada dalam proses peradilan pidana dan perampasan kemerdekaan secara nyata mengurangi hak anak yang berdampak buruk . Lapas/rutan over kapasitas, tidak nyaman, dibeberapa lapas anak masih bercampur dengan orang dewasa dan yang lebih buruk adalah isolasi dengan Keluarga, kurangnya pelayanan pendidikan/ sosial, pembinaan serta pembimbingan.

Terkait hal tersebut Wirjono Projodikoro berpendapat bahwa: dibidang hukum pidana Hakim bertugas menerapkan kedalam in concerto yaitu apa yang dilakukan oleh seseorang terdakwa khususnya anak harus sejalan dengan rumusan suatu perbuatan melanggar Hukum didalam Ketentuan Pidana untuk penetapan pidana ini, 
oleh hakim, harus mengetahui dulu pidana mana yang dilanggar dengan melihat asas legalitas yang sudah ada.

Konsepsi diatas berhubungan dengan asas legalitas tetapi perlu diingat bahwa bukan semata-mata seperti yang dirumuskan dalam pasal 1 ayat 1 KUHP "Nullum crima sine lege” tetapi juga "Nulla Punna Sine Lege" tetapi juga “ Nulla Poena Sine Lege” artinya bukan hanya mengerti pelarangan atas suatu perbuatan saja tetapi jumlah pengenaan pidana yang diancamkan harus juga ditentukan oleh undang-undang.

Dalam kerangka itulah maka perlu pula dikemukakan disini bahwa selain dibatasi oleh peraturan perundang-undangan (asas Legalitas) kebebasan atau kemerdekaan Hakim dalam memutus perkara pidana dalam proses peradilan juga dibatasi oleh dakwaan Jaksa Penuntut Umum. menurut Andi Hamzah:

"Putusan Hakim didalam perkara Pidana dibatasi pula oleh apa yang didakwakan Jaksa Penuntut Umum sama dengan perkara perdata dibatasi oleh apa yang akan digugat. Hakim tidak boleh memutus diluar dari apa yang diputuskan Jaksa..idealnya adalah perbuatan yang sungguh-sunnguh terjadi dan didakwaakan dan itupula yang dibuktikan . Memang benar "Dominis Litis" adalah jaksa (yang mengakili negara). Jaksa boleh menuntut satu feit (perbuatannya) walaupun terdakwa melakukan satu feiten (perbuatan) tetapi yang satu sungguh-sungguh terjadi dan sungguh-sungguh dibuktikan sebagai alat bukti yang cukup ditambah dengan keyakinan hakim .kebebasan menuntut jaksa dilakukan pula oleh jaksa di Amerika Serikatdengan Praktek Plea Barganning artinya jika terdakwa mengakui kesalahannya, jaksa dapat mengurangi delik yang didakwakannya.oleh karena itu kebebasan atau kemerdekaan hakim untuk memutus perkara tergantung pula pada bebas atau tidaknya penuntut umum

Tujuan Peradilan Pidana adalah untuk memutuskan apakah seseorang bersalah atau tidak peradilan pidana dilakukan dengan prosedur yang tertuang dalam peraturan perundang-undangan yang mencangkup semua batas konstitusional yang berakhir pemeriksaan di pengadilan.

Kitab Undang-undang Hukum Pidana yang selama ini ada, belum Mengatur mengenai adanya Pidana Pengawasan, terutama Pengawasan terhadap Anak. Dalam Pidana Pengawasan, didalam KUHP sendiri, Hakim berpedoman dengan Pasal 14 a KUHP adapun didalam Undang-undang Sistem Peradilan Anak, Untuk Mencegah Terjadinya Pidana Penjara yang selama ini sangat ditekankan dalam upaya pembalasan terhadap anak, maka didalam Pasal 71- Pasal 78 Undang-undang No 11 Tahun 2012.

Pidana Pengawasan sendiri didalam Undang-Undang No. 11 Tahun 2012 diatur didalam Pasal 77 yaitu:

(1) Pidana Pengawasan yang dapat dijatuhkan kepada anak sebagaimana dimaksud dalam Pasal 71 ayat 1 huruf b angka 3 paling singkat 3 (tiga) bulan dan paling lama 2 (dua) tahun 
(2) Dalam Hal Anak dijatuhi Pidana Pengawasan sebagaimana dimaksud pada ayat 1 anak ditaruh dibawah pengawasan Penuntut umum dan dibimbing oleh pembimbing kemasyarakatan.

Penjatuhan Pidana oleh Hakim sebagai corong undang-undang tidaklah salah, akan tetapi, sebaiknya hakim menimbang kembali apakah putusan tersebut memberikan keadilan dan kemanfaatan bagi anak. Khusus dalam Hal Pidana Pengawasan, lebih ditekankan hakim dalam berpikir secara fleksebilitas bagi hakim serta melihat dari latar belakang anak tersebut tujuannya adalah untuk terwujudnya Perlindungan bagi anak. Pidana Pengawasan yang diterapkan oleh hakim bertujuan untuk agar terciptanya "Social Welfare” dan "Sosial Defence"yaitu kesejatreaan masyarakat dan perlindungan sosial.

Keputusan dalam Proses Peradilan dituangkan didalam putusan hakim atau putusan peradilan. Menurut Pasal 1 angka 11 KUHP yag dimaksud putusan hakim atau putusan peradilan adalah pernyatan hakim yang diucapkan dalam sidang terbuka yang berupa pemidanaan, lepas dari segala hal tuntutan hukum dan cara yang diatur didalam undang-undang. Menurut Lilik Mulyadi hakekat Putusan Hakim Merupakan: Putusan yang diucapkan dalam sidang terbuka untuk Umum. menurut Mulyadi pada konteks ini, Putusan diucapkan oleh hakim karena jabatannya artinya hakim diberi wewenang oleh undang-undang. untuk mengadili perkara (BAB I Pasal 1 angka 8 KUHAP) Putusan Hakim tersebut kemudian haruslah diucapkan dalam persidangan yang terbuka untuk umum (Pasal 195 KUHAP, Pasal 13 Undang-undang Nomor 48 Tahun 2009 tentang Kekuasaan Kehakiman.

Dikemukakan pula bahwa Putusan dijatuhkan setelah melalui proses atau tahapan-tahapa atau persidangan dan proses administrasinya menurut hukum acara pidana pada umumnya. saja yang mempunyai kekuatan mengikat dan sah pengertian proses atau tahapan persidangan anak disini adalah:

1.Pembacaan hasil penelitian pembimbing kemasyarakatan (sebelum sidang terbuka

2. Pembukaan sidang tertutup

3. Pembacaan Dakwaan

4. Eksepsi

5. Putusan sela (sidang dilanjutkan atau eksepsi ditolak) jika dilanjutkan maka

6. Pembuktian (Pemeriksaan terdakwa, sanksi ahli, terdakwa

7. Requisitoir/tuntutan

8. Pledoi (pembelaan oleh orang tua, atau kuasa hukum/wali/orang tua asuh)

9. Putusan (sidang terbuka untuk umum)

Menurut Raws hakekat suatu putusan dikatakan adil jika: Dimana Bekerjanya Proses yudikatif"pengadilan harus berketetapan untuk menerapkan dan dan menegagkan 
peraturan perundang-undangan yang dimana dikatakan bahwa hukum itu secara rasional memberikan petunjuk-petunjuk dan memberikan arah kepada manusia. Didalam Negara Hukum dituntut adanya suatu hukum acara pidana yang merupakan suatu prosedur yang didisain untuk memastikan adanya suatu kebenaran yang cara dan jalannya sesuai dengan tujuan dari peradilan haruslah adil dan terbuka namun tidak diperbolehkan dirusak oleh tekanan politik.Esensi dari hukum yang berkeadilan adalah memastikan tatanan hukum dapat dipelihara secara tidak memihak dan teratur.

Menurut John Raws keadilan itu adalah Fairness yang mengandung asas-asas bahwa orang-orang yang merdeka dan rasional yang berkehendak untuk mengembangkan kepentingannya hendaknya memperolah kedudukan yang sama pda saat memulainnya dan itu merupakan syarat fundamental bagi mreka yang memasuki perhimpunan yang mereka kehendaki yang mengatakan bahwa keadilan adalah suatu kebijakan politik yang aturannya-aturannya menjadi dasar dariperaturan negara dan aturan-aturan ini merupakan ukuran apa yang menjadi hak.

Keadilan dapat diartikan sebagai suatu nilai untuk menciptakan hubungan yang ideal antara manusia yang satu dengan manusia yang lain sebagai sesama anggota masyarakat dengan memberikan kepada manusia apa yang menjadi haknya sesuai dengan prestasinya. dan membebankan kewajiban menurut hukum dan moral .Definisi keadilan diatas menunjukan bahwa untuk mewujudkan sesuatu itu adil tidaklah mudah seperti yang dibayangkan. adil bagi kelompok tertentu belum tentu adil bagi kelompok lainnya.

Keadilan merupakan salah satu hal yang harus diwujudkan oleh pengadilan. menurut pendapat beberapa ahli keadilan adalah salah satu tujuan hukum bagi masyarakat siapa saja . keadilan merupakan bagian yang tak terpisahkan dari hukum itu sendiri. Hukum pada Dasarnya berintikan keadilan. hukum seharusnya mengandung nilai Keadilan hal mana sesuai dengan pendapat jhon Raws yang mengatakan bahwa subyek utama keadilan adalah struktur dasar masyarakat atau lebih tepatnya cara-cara lembaga sosial mendistribusikan hak dan kewajiban fudamental serta menentukan pembagian keuntungan dan kerjasama sosial.

\section{KESIMPULAN}

Tidak dipungkiri bahwa, hakekat Putusan hakim dalam hal pidana pengawasan yang dijatuhkan bagi anak yang berhadapan hukum merupakan nilai penting bagi anak berbeda dengan kepastian hakum yang lebih bersifat menyamarkan, pada hakekat keadilan bersifat individual sehingga didalam pelaksanaan dan penegakan hukum masyarakat sangat berkepentingan. 
Pidana pengawasan merupakan alternatif yang cocok diberikan untuk anak dimana pidana pengawasan ini merupakan pilihan hakim disaat penjatuhan putusan. pidana pengawasan merupakan pidana yang diletakan pada suatu syarat tertentu jadi disini, hakim dapat memilih untuk menjatuhkan pidana yang dikaitkan dengan syarat tertentu tersebut. untuk mewujudkan suatu putusan adil bagi anak, hakim juga harus menggali lebih dalam dulu melalui intuisi hati nurai dan pikiran mereka sebelum menjatuhkan sebuah putusan.

\section{SARAN}

Sebaiknya Para Pembuat Undang-undang maupun pihak terkait segera memperbarui Undangundang didalam Sistem Peradilan Pidana Anak khususnya dalam Hal pidana pengawasan. karena disini, para pembuatundang-undang harus jelibetul dan memisahkan Kata Pidana dan Pengawasan adalah dua hal yang perlu diperbaiki dan dikaji ulang.

\section{DAFTAR BACAAN}

Dahlan Sinaga, 2015, Kemandirian, Kebebasan Hakim memutus Perkara Pidana dalam Negara Hukum Pancasilasuatu Perspektif Teori Keadilan Bermartabat

Hanafi Amrani dan Mahrus Ali, 2015, sistem Pertanggungjawban Pidana Perkembangan dan Penerapan, Rajawali Press, Jakarta

JE.Sahetapy, Hukum Pidana, Liberty, Yogyakata , h. 39

Koeswadji,1993 Hukum Pidana Lingkungan, Citra Aditya, Bandung,

Leden Marpaung, 1991 Unsur-unsur Perbuatan Yang Dapat Dihukum, (Delik), Jakarta, Sinar Grafika,

Margono, 2019, Asas Keadilan, Kemanfaatan dan Kepastian Hukum dalam Putusan Hakim

Moeljatno, 1984 Asas-asas Hukum Pidana, Cetakan Kedua, Bina Aksara, Jakarta,

Peter Mahmud Marzuki, Perlunya Undang-undang Tentang Macam dan Harga Mata Uang (penelitian) kerjasa sama dengan Bank Indonesia

Prodjohamidjoyo, 1997 Memahami Dasar-Dasar Hukum Pidana, Pradnya Paramita, Jakarta 
Sajipto Raharjo, 2009, Penegakan Hukum : Suatu Tinjauan Sosiologis, Genta Publishing, Yogyakarta

Sudikno Mertokusumo, 1999 Mengenal Hukum Sebab Pengantar, Liberty, Yogyakarta,

\section{B. Peraturan Perundang-undangan}

a. UU No. 8 Tahun 1981 tentang Hukum Acara Pidana yang dundangkan dalam: (Lembaran Negara Tahun 1981 No. 9 Tambahan LN RI No.81)

b. UU No. 11 Tahun 2012 tentang Sistem Peradilan Pidana Anak

c. UU No 23 Tahun 2002 Tentang Perlindungan Anak

d. UU No. 48 Tahun 2009 Tentang Kekuasaan Kehakiman 